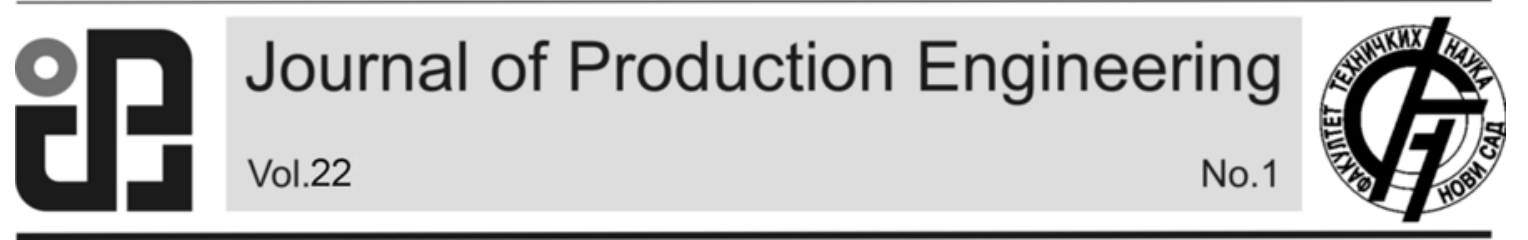

JPE (2019) Vol.22 (1)

Amiolemhen, P.E., Ogie, A.N.

Original Scientific Paper

\title{
DESIGN AND MANUFACTURE OF A 10-TONNE HYDRAULIC PRESS
}

Received: 27 February 2019 / Accepted: 25 May 2019

\begin{abstract}
The design and construction of a 10-ton hydraulic press for laboratories use in most of our higher institutions using locally sourced materials was carried out. Frames and cylinders are the main components of the hydraulic press. An existing design was examined and the basic features and components were identified after which a market survey was conducted to access the availability or otherwise of the components. The major components of the press designed include the cylinder and piston arrangement, the frame and the hydraulic circuit. The machine was then designed and produced according to specification and was subsequently calibrated and tested. The principal parameters of the design included the maximum load 10 tonnes, the distance the load resistance has to move, the system pressure, the cylinder area and the volume flow rate of the working fluid.
\end{abstract}

Key words: Hydraulic press, load, pressure gauge, piston, cylinder.

Projektovanje i proizvodnja hidraulične prese do 10 tona. Izvršeno je projektovanje i izgradnja 10-tonske hidraulične prese za laboratorijske potrebe za većini naših visokih ustanova koristeći lokalno nabavljene materijale. Okviri i cilindri su glavne komponente hidraulične prese. Proučen je postojeći dizajn i identifikovane su osnovne karakteristike $i$ komponente, nakon čega je sprovedeno istraživanje tržišta kako bi se pristupilo dostupnosti komponenti. Glavni sastavni delovi presa obuhvataju raspored cilindara i klipova, okvir $i$ hidraulični prsten. Mašina je zatim dizajnirana i proizvedena u skladu sa specifikacijom i naknadno je kalibrisana i testirana. Glavni parametri projekta su maksimalno opterećenje do 10 tona, rastojanje koje mora da prenese, opterećenje sistema, područje cilindra i zapreminski protok radnog fluida.

Ključne reči: Hidraulična presa, opteréenje, manometar, klip, cilindar.

\section{INTRODUCTION}

Presses, as defined by Lange [1], are pressure exerting machine tools. He noted that force and energy are very important characteristic parameters in presses. And depending upon the method of making this force available, he classified pressure-exerting machines into three categories: as Presses controlled by work capacity (Energy) (e.g. Hammer and Screw presses); Presses controlled by force (e. g. Hydraulic presses) and Presses controlled by travel (stroke) (e.g. Crank and cam mechanical presses).

Sullivan [2] classified hydraulic pumps into two broad groups; Positive displacement pumps (whereby pumping action displaces a specific amount of fluid per revolution) and Non positive displacement pumps (whereby pumps using the inertia principle to propel the fluid).

Linear actuators (or hydraulic cylinders) may be single acting or double- acting type. The former type permits the application of hydraulic pressure in one direction only and requires a retracting mechanism to return it to initial position [2].

Hydraulic presses can be classified into three principal categories as: hydraulic presses which operate on the principles of hydrostatic pressure, screw presses which use power screws to transmit power and mechanical presses which utilize kinematic linkage of elements to transmit power [3], [4].

However, Degarmo et al [5] classified presses in to three broad categories based on: Drive mechanism (mechanical, hydraulic or screw); Capacity (hydraulic presses have higher capacities, in excess of 50, 000 Tonnes) and Frame construction (open or close frames).

A typical hydraulic press consists of a pump which provides the motive power for the fluid, the fluid itself which is the medium of power transmission through hydraulic pipes and connectors, control devices and the hydraulic motor which converts the hydraulic energy into useful work at the point of load resistance [4].

Many researches have been done on the design and development of hydraulic press with particular reference to the components of the machine, such as the hydraulic cylinder, piston, frame and hydraulic circuit [6], [7], [8], [9], [10].

A critical look at mechanical workshops in Nigeria reveals that majority of press machines are imported into the country and this is done at high cost. Hence, it is expedient that more of such important machine be developed locally [6]. This work therefore presents the design and development of a 10 tonnes manually operated hydraulic press, which is of low cost and can compete favourably with imported press machines of the same designed capacity.

\section{METHODOLOGY}

\subsection{Material Selection}

In this design, the main components of the machine are made of mild steel. This is because of its cost, availability and the ability to lend itself to the manufacturing process employed. 


\subsection{Design considerations}

Design load $=10$ tonnes $(10,000 \mathrm{~kg})$

Applied load, $\mathrm{F}=98,100 \mathrm{~N}$

Maximum Press Force $=101,000 \mathrm{~N}$

Maximum working Pressure, $\mathrm{P}=70 \mathrm{~N} / \mathrm{mm}^{2}$ (700 Bar)

\subsection{Design of hydraulic cylinder}

\subsubsection{Design of inner diameter of the hydraulic} cylinder

The inner diameter of the hydraulic cylinder was determined by eqn. (1) as $42.24 \mathrm{~mm}$ :

$$
\mathrm{d}_{\mathrm{ci}}=\sqrt{\frac{4 \mathrm{~F}}{\pi \mathrm{P}}}
$$

where: $\mathrm{F}=$ Applied load $=98,100 \mathrm{~N}$ and $\mathrm{P}=$ working pressure $=70 \mathrm{~N} / \mathrm{mm}^{2}$.

\subsubsection{Design of wall thickness of the hydraulic cylinder}

From Mudennavar et al [10], the Clavarino's Equation for closed-end cylinders (or cylinders fitted with heads) was used to compute the maximum wall thickness of the hydraulic cylinder as $7.58 \mathrm{~mm}$ from eqn. (2):

$$
\mathrm{t}_{\mathrm{c}}=\mathrm{r}_{\mathrm{ci}}\left[\sqrt{\frac{\left(\sigma_{\mathrm{t}}+(1-2 \mu) \mathrm{P}\right)}{\left(\sigma_{\mathrm{t}}-(1-\mu) \mathrm{P}\right)}}-1\right]
$$

where: $r_{\mathrm{ci}}=$ internal radius of the hydraulic cylinder $=$ $21.12 \mathrm{~mm} ; \mathrm{P}=$ working pressure $=70 \mathrm{~N} / \mathrm{mm}^{2} ; \sigma_{\mathrm{t}}=$ allowable tangential stress $=140 \mathrm{~N} / \mathrm{mm}^{2}$ and $\mu=$ Poison's ratio $=0.30$

\subsubsection{Design of outside diameter of the hydraulic cylinder}

The outside diameter of the cylinder, $d_{o c}$ was computed as $57.4 \mathrm{~mm}$ from eqn. (3):

$$
\mathrm{d}_{\mathrm{co}}=\mathrm{d}_{\mathrm{ci}}+2\left(\mathrm{t}_{\mathrm{c}}\right)
$$

Where: $\mathrm{d}_{\mathrm{ci}}=$ inner diameter of the hydraulic cylinder $=$ $42.24 \mathrm{~mm}$ and $\mathrm{t}_{\mathrm{c}}=$ hydraulic cylinder wall thickness $=$ $7.58 \mathrm{~mm}$.

\subsubsection{Maximum tangential stress in the hydraulic cylinder}

The maximum tangential stress in the hydraulic cylinder was determined as $128.4 \mathrm{~N} / \mathrm{mm}^{2}$ from eqn. (4):

$$
\sigma_{\mathrm{t}, \max }=\mathrm{P}\left(\frac{\mathrm{d}_{\mathrm{co}}^{2}+\mathrm{d}_{\mathrm{ci}}^{2}}{\mathrm{~d}_{\mathrm{co}}^{2}-\mathrm{d}_{\mathrm{ci}}^{2}}\right)
$$

where: $d_{\mathrm{ci}}=$ inner diameter of the hydraulic cylinder $=$ $42.24 \mathrm{~mm} ; \mathrm{d}_{\mathrm{co}}=$ outside diameter of the hydraulic cylinder $=57.4 \mathrm{~mm} ; \mathrm{P}=$ working pressure $=70 \mathrm{~N} / \mathrm{mm}^{2}$ and $\sigma_{\text {all }}=$ allowable tensile stress $=140 \mathrm{~N} / \mathrm{mm}^{2}$.

\subsubsection{Design of the hydraulic cylinder end-cover plate thickness}

The hydraulic cylinder end-cover plate thickness $t$ was computed as $10.45 \mathrm{~mm}$ from eqn. (5):

$$
\mathrm{t}=\mathrm{kd}_{\mathrm{ci}} \sqrt{\frac{\mathrm{P}}{\sigma_{\text {all }}}}
$$

Where: $d_{c i}=$ inner diameter of the hydraulic cylinder $=$
$42.24 \mathrm{~mm} ; \mathrm{k}=0.35$, fixed end cylinder [11]; $\mathrm{P}=$ working pressure $=70 \mathrm{~N} / \mathrm{mm}^{2}$ and $\sigma_{\text {all }}=$ allowable tensile stress $=140 \mathrm{~N} / \mathrm{mm}^{2}$.

\subsubsection{Design of the hydraulic press piston}

\subsubsection{Design of piston head diameter}

The piston head diameter was equated to the internal cylinder diameter of $42.24 \mathrm{~mm}$.

\subsubsection{Design of piston rod diameter}

The piston rod diameter was computed as $29.87 \mathrm{~mm}$ from eqn. (6):

$$
d_{\text {pr }}=d_{\text {ci }} \sqrt{\frac{P}{\sigma_{\text {all }}}}
$$

where: $\mathrm{d}_{\mathrm{ci}}=$ inner diameter of the hydraulic cylinder $=$ $42.24 \mathrm{~mm} ; \mathrm{P}=$ working pressure $=70 \mathrm{~N} / \mathrm{mm}^{2}$ and $\sigma_{\text {all }}=$ allowable tensile stress $=140 \mathrm{~N} / \mathrm{mm}^{2}$.

Since the values of the inside/outside diameter of the hydraulic cylinder, the working pressure, as well as the piston parameters matches that of a standard manual hydraulic cylinder and pump available; we then selected for use the Enerpac 10 Tons general purpose hydraulic jack RC106.

The specifications of the 10 tons ENERPAC hydraulic jack [12] include:

Maximum Operating Pressure: 700 bar $\left(70 \mathrm{~N} / \mathrm{mm}^{2}\right)$

Capacity Class: 10 Tons

Maximum Cylinder Capacity Advance: $101 \mathrm{KN}$

Stroke: $156 \mathrm{~mm}$

Collapsed Height of piston: $247 \mathrm{~mm}$

Height of cylinder: $403 \mathrm{~mm}$

Return Type: Single-Acting, Spring Return

Outside Diameter: $57 \mathrm{~mm}$

Cylinder Bore Diameter: $42.9 \mathrm{~mm}$

Plunger Diameter: $38.1 \mathrm{~mm}$

Base to Advance Port: $19 \mathrm{~mm}$

\subsubsection{Design of the hydraulic pump}

The hydraulic pump selected for the 10 tons hydraulic press was the 10 tons ENERPAC hydraulic hand pump with the following specifications and dimensions [12]:

Maximum Operating Pressure $=700 \mathrm{bar}=70 \mathrm{~N} / \mathrm{mm}^{2}$

Cylinder Compatability: Single-acting

Reservoir Capacity: $901 \mathrm{~cm}^{3}$

Maximum Flow at Rated Pressure: $2.47 \mathrm{~cm} 3 /$ stroke

Piston Stroke: $25.4 \mathrm{~mm}$

Valve Operation: Manual

Handle length: $522 \mathrm{~mm}$

\subsubsection{Hydraulic pipes, hoses and fittings}

The pressure hose of internal/external diameters of $9.7 \mathrm{~mm} / 19.7 \mathrm{~mm}$ respectively was selected from the available ranges of Enerpac high pressure hydraulic hoses.

\subsubsection{Design of the hydraulic press frames}

The components of the frame of the hydraulic press include: column; top cross frame; moving frame; moving frame supports pins; base frame or support; platens. 


\subsubsection{Design of the column}

Sizing the double wide $\mathrm{U}$ - channel cross beams in tension to 10 tons, the minimum cross sectional area of the $\mathrm{U}$ - channel was determined as $510.94 \mathrm{~mm}^{2}$ from eqn. (7); and the selected $U$ - channel specifications was $100 \times 50 \times 7.5 \mathrm{~mm}$ with cross-sectional area of 1175 $\mathrm{mm}^{2}$.

$$
A_{\text {min }}=\frac{F}{\sigma_{t} / S . F}
$$

where: $\mathrm{F}=$ applied load $=98,100 \mathrm{~N}$; S.F $=$ safety factor $=2.5$ and $\sigma_{\mathrm{t}}=$ tensile stress $=480 \mathrm{~N} / \mathrm{mm}^{2}$.

\subsubsection{Design of top cross frames/moving frame}

The selected $U$ - channel for the top cross frames and the moving frame was: $100 \times 50 \times 7.5 \mathrm{~mm}$ with cross-sectional area of $1175 \mathrm{~mm}^{2}$.

\subsubsection{Design of the platens}

The minimum thickness of the platens, $t_{p}$ was computed to be $17.03 \mathrm{~mm}$ using eqn. (8):

$$
t_{p}=\sqrt{\frac{6 M}{\sigma_{a l l} b}}
$$

where: $\mathrm{M}=$ maximum bending moment $=2320 \mathrm{Nm} ; \mathrm{b}=$ width of platens $=160 \mathrm{~mm}$ and $\sigma_{\text {all }}=$ allowable tensile stress for the platens material $=300 \mathrm{~N} / \mathrm{mm}^{2}$.

\subsubsection{Design of moving frame supports diameter}

The diameter of the moving frame supports diameter was computed as $18.32 \mathrm{~mm}$ from eqn. (9):

$$
\mathrm{d}_{\mathrm{s}}=\sqrt{\frac{8 \mathrm{~F}}{3 \pi \tau_{\mathrm{all}}}}
$$

where: $\mathrm{F}=$ applied load $=98,100 \mathrm{~N}$ and $\tau_{\text {all }}=$ allowable shear stress for the pin material $=248 \mathrm{~N} / \mathrm{mm}^{2}$.

\subsubsection{Design of bolts/nuts}

The top cross support beams of the hydraulic cylinder were secured by means of 8 bolts to the vertical frame. The major diameter of the bolts was computed as $22.81 \mathrm{~mm}$ from eqn. (10):

$$
\mathrm{d}_{\mathrm{b}}=\sqrt{\frac{4 \mathrm{~F}}{3 \mathrm{n} \tau_{\mathrm{all}}}}
$$

where: $\mathrm{F}=$ applied load $=98,100=8 \mathrm{~N} ; \mathrm{n}=$ number of bolts $=8$ and $\tau_{\text {all }}=$ allowable shear stress for the bolts material $=30 \mathrm{~N} / \mathrm{mm}^{2}$.

The bolts and nuts were selected according to IS: 4218 (part III) 1976 (reaffirmed 1996) [11] and this corresponds to coarse series M22 x 2.5 designation. The diameter for the bolt is chosen to be $22.00 \mathrm{~mm}$

\subsection{Machine description}

The capacity of the machine is 10 tons and working pressure of $70 \mathrm{~N} / \mathrm{mm}^{2}$ and overall dimension: $1200 \mathrm{~mm}$ high; $508 \mathrm{~mm}$ long and base width of $508 \mathrm{~mm}$. The machine consists of hydraulic jack, pressure gauge, hydraulic hand pump; two end end-cover plates; top cross and moving frames. The hydraulic press frame consists of components: column; top cross frame; moving frame; moving frame supports pins; base frame or support; platens. The hydraulic jack is a singleacting cylinder with a stroke of $156 \mathrm{~mm}$ consists of piston head diameter of diameter $42.24 \mathrm{~mm}$ and plunger diameter $38.1 \mathrm{~mm}$. The hydraulic pump handle length is $522 \mathrm{~mm}$. It also consists of pressure hose of internal/external diameters of $9.7 \mathrm{~mm} / 19.7 \mathrm{~mm}$ respectively. The column, top cross and moving frames are made from $100 \mathrm{~mm}$ by $50 \mathrm{~mm}$ by $7.5 \mathrm{~mm} \mathrm{U}-$ channel. The platens and the two end end-cover plates of thickness $20 \mathrm{~mm}$. The frames are held rigidly together by means of M22 bolts and nuts.

The frame which is made of mild steel material was made to provide the mounting base for all other components of the machine and its rigidity determines the rigidity of the entire machine.

\subsection{Performance Test}

\subsubsection{Performance Test under no-load.}

Under this condition, the piston was observed to be displaced from the cylinder very well beyond the designed stroke. No leakages observed in the system throughout the four (4) hours period of this test. This indicates that the machine performed very well under no load conditions.

\subsubsection{Performance Test under on load.}

This test was also carried out for four (4) hours. Under loading there was no leakage observed as well, since the pressure gauge pointer was observed to be in the same position throughout the period it was allowed to stand.

\section{RESULTS AND DISCUSSION}

The hydraulic press structure has been analysed theoretically and experimentally and the following results were derived:

Length of material $=0.3 \mathrm{~m}$

Breadth of material $=0.2 \mathrm{~m}$

Area of material $=0.3 \times 0.2=0.6 \mathrm{~m}^{2}$

The Table 1 and Figure 1 shows the stress and strain relationship. For the stress and strain at different loads, we have:

\begin{tabular}{|c|c|c|c|c|}
\hline S/N & $\begin{array}{c}\text { Load (P) } \\
(\mathbf{K N})\end{array}$ & $\begin{array}{c}\text { Deflection } \\
(\mathbf{m})\end{array}$ & $\begin{array}{c}\text { Stress } \\
\left(\mathbf{K N} / \mathbf{m}^{\mathbf{2}}\right)\end{array}$ & Strain \\
\hline 1 & 2 & 0.0050 & 3.33 & 0.0017 \\
\hline 2 & 4 & 0.0010 & 6.67 & 0.0033 \\
\hline 3 & 6 & 0.0015 & 10.00 & 0.0050 \\
\hline 4 & 8 & 0.0020 & 13.33 & 0.0067 \\
\hline 5 & 10 & 0.0025 & 16.67 & 0.0083 \\
\hline
\end{tabular}

Table 1. Test result showing stress and strain

\subsection{Cost Estimate}

The cost estimate for the hydraulic press was N340,240 (about US\$1000) at prices in Benin City, Nigeria as at the time of press manufacture. However, the unit cost of a product in most cases is several times higher than for quantity based production [13]. Hence, the items bought were as required for the press manufacture. The cost of labor, transportation and contingencies were also included in the cost estimate. 


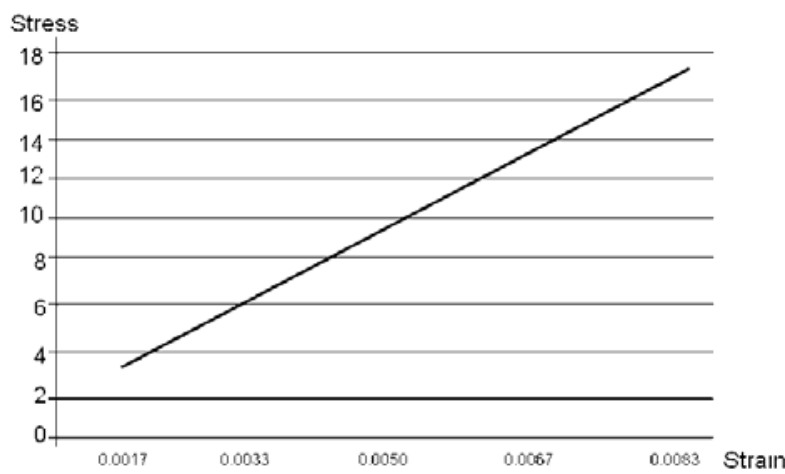

Fig. 1. Stress/strain relationship

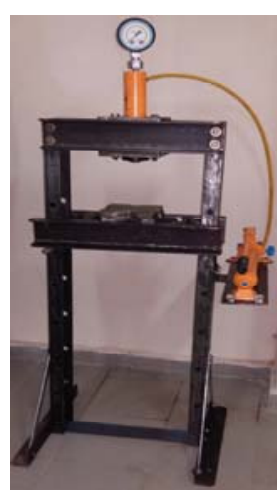

Fig. 2. Pictorial view of the 10 tons hydraulic press

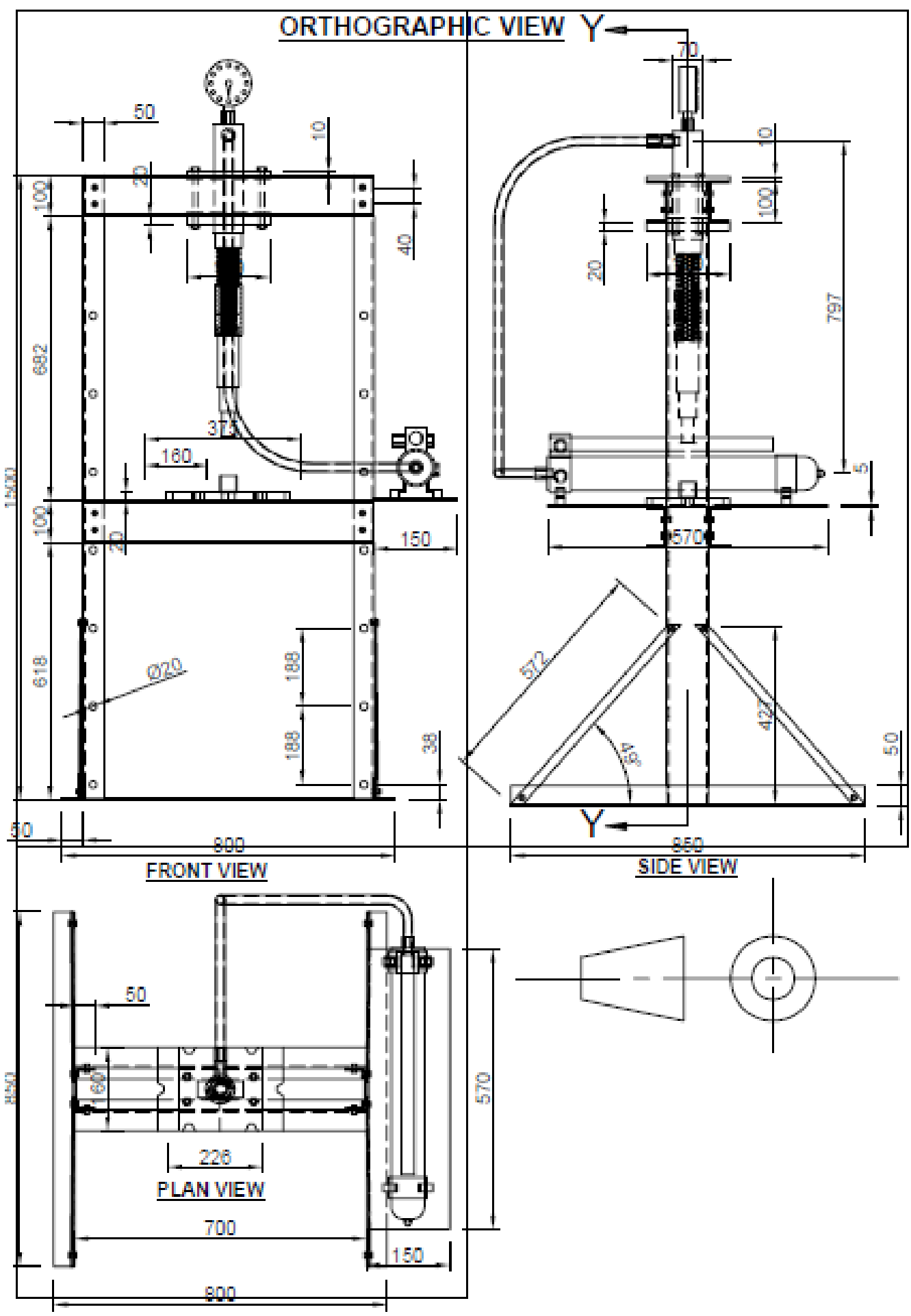

Fig. 3. Orthographic view of the 10 tons hydraulic press 


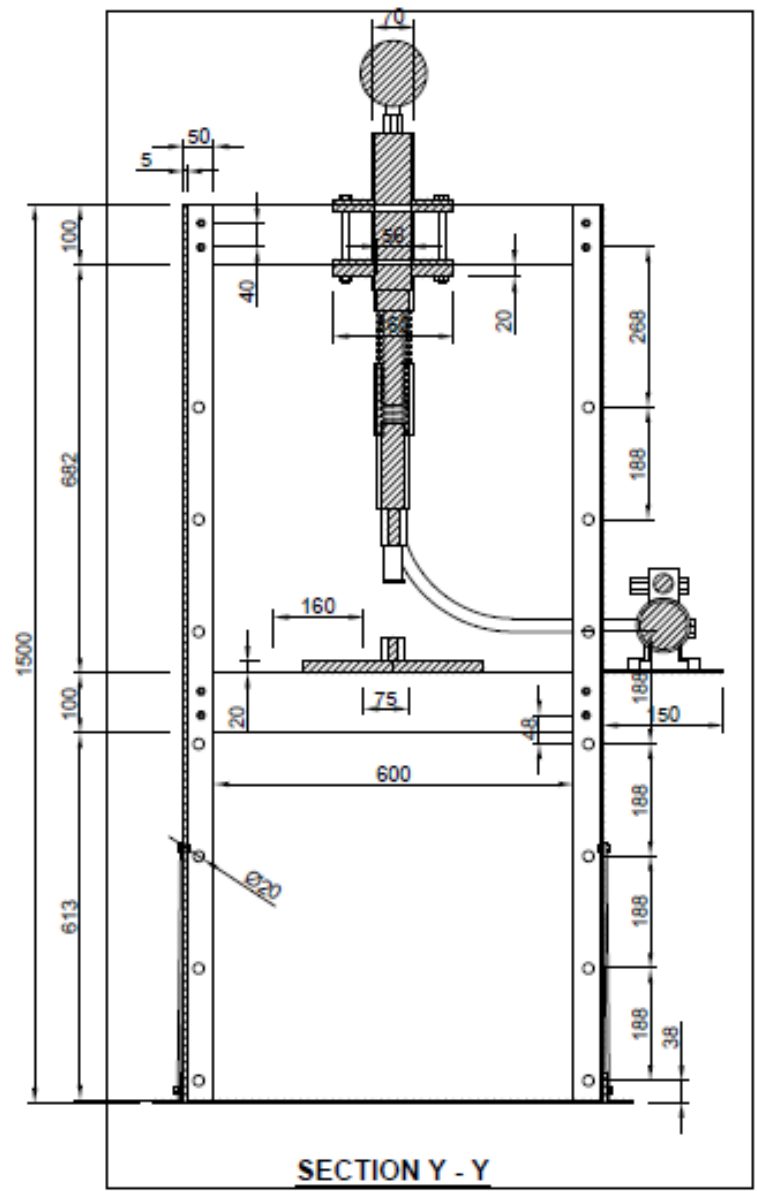

Fig. 4. Sectional view of the 10 tons hydraulic press

\section{CONCLUSION}

A hand-operated 10 ton hydraulic press has been designed, manufacture and calibrated. The machine was tested to ensure conformability and serviceability to design objectives. The machine was found to be satisfactory at a test load $10 \mathrm{KN}$.

\section{REFERENCES}

[1] Lange, K. Handbook of metal forming. McGrawHill, New York, NY, USA. 1975.

[2] Sullivan, J.A. Fluid power: Theory andApplications. Reston Publishing, Reston, VA, USA. 1975.

[3] Degarmo, E.P.; Black, J.T.; and Kohser, R.A. Materials and processes in manufacturing. 8th ed, Prentice-Hall of India, New Delhi, India, pp. 546-52. 1997.

[4] Sharma, P.C. A textbook of production engineering. 10th ed., S. Chand \& Co. Ltd., Ram Nagar, New Delhi, India. 2005.

[5] Degarmo, E. R. Black, J. T. and Ronald, A. K. Material Processes in Manufacturing, Prentice-Hall of India, New Delhi, $8^{\text {th }}$ Edition, Pp 546 - 552. 1996.

[6] Sumaila, M. and Ibhadode, A. O. A. Design and manufacture of a thirty-ton hydraulic press. Assumption University Journal of Technology. 4, 196 - 200. 2011.

[7] Yang, K., Guan, S. and Wang, C. The design and calculation for hydraulic cylinder of workpiece hydraulic clamping system of a special CNC machine for guide disc. Procedia Engineering. 16. 418 - 422. 2011.

[8] More, D. A., Chhapkhane N. K. and Kolhe, R. Design, Development and Optimization of Hydraulic Press. International Journal for Research in Applied Science \& Engineering Technology (IJRASET). Vol.2, No. 6, 902 - 907. 2015.

[9] Nwankwojike, B. N., Nwogu, C. N. and Kalu, G. Development of a Manually Operated Hydraulic Press and Pull Machine. FUOYE Journal of Engineering and Technology, Vol. 2, No. 2, 73 -78. 2017.

[10] Mudennavar, G. M., Chalageri, G. and Patil, P. A. Design and Analysis of 12 Ton Hydraulic Pressing Machine. International Journal of Scientific Development and Research (IJSDR. Vol. 3, No. 8. $109-117.2018$.

[11] Khurmi, R. S. and Gupta, J. K. A textbook of Machine Design, Eurasia Publishing House Ltd, New Delhi. 1997.

[12] ENERPAC Africa (PTY) Ltd, 5 Bauhinia Avenue, Cambridge Office Park Block E, Highveld Techno Park, Centurion 0157, Republic of South-Africa.

[13] Dagwa, I.M.; and Ibhadode, A.O.A. Design and manufacture of automobile disk brake pad test rig. Nigerian Journal of Engineering Research and Development 4(3): 15-24. 2005

Authors: Patrick Ejebheare Amiolemhen (Ph.D.), Associate Prof.., Engr. Ogie, Nosa Andrew (Ph. D student)

Department of Production Engineering, Faculty of Engineering, University of Benin, P.M.B. 1154, Benin City, Nigeria.

Department of Mechanical Engineering, Petroleum Training Institute, Effurun, Delta State, Nigeria.

Email: patrick.amiolemhen@uniben.edu; ogie_na@pti.edu.ng 